\title{
Investment Issues in Emerging Markets: A Review
}

\author{
C. Mitchell Conover, CFA, CIPM \\ Associate Professor, Robins School of Business \\ University of Richmond, Richmond, Virginia
}

\begin{abstract}
Emerging markets have generated considerable interest among investors and academics. Although their returns are increasingly converging to those of the developed world because of integration and liberalization, they still provide benefits to a global portfolio. This review reflects the latest practitioner and academic work on emerging market investing.
\end{abstract}

Because of their higher economic growth and potentially higher returns, emerging markets have received increasing attention from investors in the developed world. They are also said to provide diversification benefits for U.S. investors because of their low correlations with U.S. assets.

It is well documented that the benefits of international diversification within developed markets have declined over time because of increasing correlations. Emerging markets, however, offer both lower correlations and an expanded number of markets to invest in, as demonstrated in Goetzmann, Li, and Rouwenhorst (2005). More recently, Eun and Lee (2010) have confirmed that, although their performance is converging to that of developed markets, emerging markets are still more distinct from one another than developed markets are and still provide diversification benefits to the global investor.

Also increasing their exposure is the ability of emerging markets to provide benefits to the developed world on a global macroeconomic level. As Sullivan (2008) notes, the continued growth of emerging markets means that the U.S. economy is more diversified across countries because it does not depend solely on developed markets. If stronger economic growth in emerging markets implies higher stock returns, then the developed world should allocate more capital to them. This increased investment would strengthen emerging market currency values and market capitalizations. As a result, their representation in a well-diversified global portfolio and their importance in the global economy would increase in the future.

Despite the attractiveness of emerging markets, investing in them has many issues and associated risks that are not present in the developed world. In the past several years, a great deal of research has been conducted on emerging market issues. The most prominent areas are those concerning nonnormality and synchronicity in returns, corporate governance, contagion, changes from integration and liberalization, return factors, institutional investor and analyst performance, and currency issues.

The purpose of this literature review is to provide a comprehensive summary of recent research relevant for emerging market investors. This review updates and complements the review of emerging market investment issues by Schill (2008) and the review of emerging market central banks and monetary policy by DeRosa (2009).

\section{Nonnormality and Synchronicity in Returns}

It is generally accepted that emerging market stock returns are not normally distributed. Extreme returns are more frequent than under a normal distribution, which results in a fat-tailed (leptokurtic) distribution. Both large positive (positive skewness) and large negative (negative skewness) returns have been found in various emerging markets. These return distributions violate the normality assumption in the mean-variance analysis framework commonly used in portfolio management. 
Extreme returns can have a tremendous impact on a portfolio's terminal value. Estrada (2009) examines more than 110,000 daily returns for 16 emerging equity markets. Each market had an average of 111 outlier returns, versus the 19 expected under a normal distribution. On the one hand, if an investor had avoided the 10 worst days in returns, the terminal value of the portfolio would have been 337 percent more valuable. On the other hand, if an investor had missed the 10 best performing days, the terminal value would have been 69 percent lower. Furthermore, these 10 days constituted only 0.15 percent of the days examined, which means that market timing in emerging markets would be very challenging, if not impossible. The implication is that investors should broadly diversify in emerging markets to dampen the influence of negative outliers while maintaining exposure to large positive returns.

Bae, Lim, and Wei (2006) argue that positively skewed returns in emerging markets are a result of risk sharing and poor corporate governance. Many emerging markets contain families of companies, and a family will not let an individual member experience financial distress. Companies with poor governance usually have poor information disclosure and often will hide bad news or release it only slowly. The result is that positively skewed returns will be more common than negatively skewed returns. The authors document that emerging market returns are positively skewed when ownership is concentrated, when a company is part of a family, and when governance is poor.

Jin and Myers (2006) use the concept of opaqueness as an explanation for negatively skewed returns in emerging markets. ${ }^{1}$ If a company operates with little transparency to its outside investors, insiders will be likely to release bad news only when forced to by dire circumstances. The release will more than likely result in large stock price declines. Furthermore, with opaqueness, insiders may be tempted to skim the company's cash flows when times are good and reduce skimming when times are bad. Insiders, therefore, absorb more of a company's specific risk. As a result, in countries where company information is opaque, the primary driver of stock returns is systematic risk and the $R^{2}$ between company returns is higher. The higher $R^{2}$ is referred to as stock price synchronicity. The authors control for country risk and use five measures of opaqueness to find that higher opaqueness is associated with higher $R^{2} \mathrm{~s}$ and higher crash frequencies. Herding behavior among noise traders also increases the $R^{2}$ s. The results suggest that opaqueness is related to an emerging market's $R^{2}$.

Another explanation for high $R^{2}$ s in emerging markets is the type of information analysts produce. If emerging market analysts do not produce much company-specific information because property rights are weak, then the information they do produce will be predominantly marketwide. Essentially, analysts will not have an incentive to produce company-specific information if property rights are weak because the production of such information will not lead to superior performance.

Chan and Hameed (2006) find that greater analyst coverage increases the synchronicity of stock prices in emerging markets, which is consistent with analysts producing primarily marketwide information. Furthermore, the returns of stocks with high analyst coverage lead those with low coverage, which implies that the prices of companies with high analyst coverage reflect marketwide information more quickly. Lastly, the aggregate earnings forecasts for high-coverage stocks affect the returns of those with less analyst coverage.

The idea that analysts produce marketwide information for emerging market companies is confirmed by examining companies that have cross-listed their stocks on a foreign exchange. Fernandes and Ferreira (2008) measure the informativeness of a company's stock price using the variation in the company-specific component. The variation in the proportion of a company's stock return not caused by market movements measures informativeness, with lower volatility indicating less informativeness. For emerging market companies that are cross-listed on a U.S. exchange, the informativeness of their stock price is lower than that of non-listed companies. The authors attribute this result to increased analyst coverage for cross-listed companies. If analysts produce primarily marketwide information for emerging market stocks, then prices should be more closely associated with market movements, which is in contrast to developed market companies, where cross-listing increases informativeness. The increase in informativeness is highest for companies from countries where investor protection is high.

1For a thorough review of synchronicity in emerging markets, as well as other investing issues, see Schill (2008). 
In sum, emerging market returns are nonnormal, which has significant implications for investors. Positively and negatively skewed returns are a result of company ownership, corporate governance, and opaqueness. Return synchronicity is a result of opaqueness and the marketwide information that analysts produce for emerging market companies.

\section{Corporate Governance}

Emerging countries typically have weak investor protections. ${ }^{2}$ Although corporate governance practices are improving, Bekaert and Harvey (2003) provide several examples of the weaknesses found in emerging countries:

- Management uses its control for perquisite consumption.

- Company shares are owned by another company that exerts control.

- Creditor rights are often strong to the detriment of shareholders.

One method of determining the value of better shareholder protection is to examine the gains to acquirers of emerging market companies. In the United States, it has been extensively documented that, on average, acquirers pay too much for target companies and that gains accrue only to target shareholders in a merger. In the case of emerging market targets, however, Chari, Ouimet, and Tesar (2010) discover that acquirer shareholders often benefit from an acquisition. The gains are substantial, averaging about 10 percent of target value, and are larger when there is weaker shareholder protection in the emerging market target country. There are no gains when the acquirer buys a minority stake. The gains are smaller when both the target and acquirer are emerging market companies. These results are consistent with acquirers' gaining by instituting better corporate governance practices at the target. These protections for shareholders are especially important when intangible assets, such as patents, are involved.

Likewise, Bris and Cabolis (2008) show that target shareholder excess returns increase when an acquirer is located in a country with better shareholder protection and accounting standards. The acquisitions studied were those for control, where the target companies adopt the more stringent practices of the acquirer.

Morey, Gottesman, Baker, and Godridge (2009) determine that improvements in corporate governance of emerging market companies are accompanied by increases in company value, as measured by Tobin's $q$ and the market-to-book ratio. Additionally, improvements in country risk are related to improved governance at the company level.

It is generally believed that English common law countries (typically Great Britain and its former colonies) provide greater protection to shareholders than code law countries. Conover, Miller, and Szakmary (2008) report evidence suggesting that investor protection varies systematically by a country's legal origin. They report that companies in code law countries take longer to file their financial statements and that the incidence of late filing is higher.

Fan and Wong (2005) find that controlling shareholders in emerging markets can signal the quality of the company's financial statements by hiring a "Big 5" auditor. In these cases, minority shareholders do not face as much of a discount for their shares. In addition, Aggarwal, Klapper, and Wysocki (2005) determine that mutual fund managers will invest more in companies that have more transparent accounting as well as in those countries with superior accounting standards, legal systems, and shareholder protections. Greater investments are also made in companies that have their stocks listed in the United States using American Depositary Receipts (ADRs), which are thought to provide the investor greater protection (for further discussion on this topic, see the section in this review on the changes from market integration and liberalization).

In summary, improvements in corporate governance of emerging market companies increase shareholder wealth, company valuation, and investor interest. Corporate governance is related to country risk and legal origin.

2For a comprehensive review of shareholder rights in developed and several emerging markets, see Schacht, Allen, and Orsagh (2009). 


\section{Contagion}

Although most studies find that emerging markets have return and diversification benefits over the longer term, there have been shorter periods when emerging markets have decreased the return and increased the risk of a global portfolio. Tokat and Wicas (2004) attribute these periods to contagious emerging market crises, where bear markets and currency devaluations spread from one emerging country to another. They find that during contagion periods, emerging market returns are lower, risk is higher, and the correlations with developed markets are higher.

Bekaert and Harvey (2003) provide five reasons for contagion. First, a country might devalue its currency to keep its exports competitive with other countries that devalued. Second, a country may experience a decline in exports to countries in crisis. Third, the initial crisis may alert investors that other countries have weaknesses. Fourth, margin calls from the initial crisis may cause investors to liquidate assets in other countries. Fifth, a crisis in one country may lead to a credit crunch in others. Incidentally, DeRosa (2009) notes that countries with fixed exchange rates suffer the shocks from a withdrawal of capital to a greater degree than countries with flexible exchange rates.

Boyer, Kumagai, and Yuan (2006) examine two possible explanations for contagion: investor wealth constraints and fundamentals. In the first case, a crisis in Country A may spread to Country B if losses in Country A force investors to liquidate investments in Country B. In the second case, weakening fundamentals in Country A may spread to Country B, causing depreciation in Country B assets.

One method of testing these explanations is to examine the co-movement between Country A and Country $\mathrm{B}$ stocks by using stocks accessible and inaccessible to foreign investors. If wealth constraints explain contagion, then the co-movement between accessible stocks during a crisis will be greater than that between inaccessible stocks. Alternatively, if fundamentals explain contagion, then the co-movement for accessible and inaccessible stocks will be similar.

Additionally, the decline in Country B asset prices may force local investors to liquidate. If the contagion is caused by investor wealth constraints, then accessible stock prices will lead inaccessible stock prices. The comovement between stocks should also be higher during market downturns than during upturns. Based on the 1997 Asian crisis, the evidence supports the hypothesis that wealth constraints are responsible for contagion in financial markets, not market fundamentals.

Other research by Chandar, Patro, and Yezegel (2009) shows that the cross-listing of stocks does not appear to be a cause of contagion. During currency crises, they find that in the crisis country, cross-listed shares have less negative returns relative to shares that are not cross-listed. In the contagion countries, cross-listed shares do not have significantly different returns. These results hold after controlling for other company and country characteristics.

Another explanation for contagion from Chiang and Zheng (2010) is investor herding behavior. During crisis periods, herding behavior increases in the crisis country, which then results in crises in other countries. Outside the crisis periods, herding behavior is found in advanced (except the U.S.) and Asian markets. Interestingly, the authors also find that investors in Latin America herd around U.S. returns more than they do their own market returns.

Markwat, Kole, and van Dijk (2009) report that global crises are not abrupt and tend to be preceded by local or regional crashes. Higher interest rates and higher stock market volatility precede crises. In emerging markets, higher bond returns decrease the probability of a crisis.

Evidence of contagion has also been found between the bond and equity markets of different countries. Ferreira and Gama (2007) find that when a government's bonds are downgraded, a negative stock market reaction takes place in another country. This effect is stronger in emerging markets and is asymmetric because credit upgrades are not related to stock market changes in other countries. The equity spillover effect is stronger when the countries are closer geographically and is stronger for industries that are smaller and involve tradable goods.

Examining emerging bond markets, Bunda, Hamann, and Lall (2009) provide evidence that historically, contagion has been declining, which appears to be the result of global investors better discerning the risks of particular markets. The 2008 demise of Lehman Brothers, however, brought about increased correlations in emerging market bond returns. 
The recent U.S. financial crisis has been studied by Dooley and Hutchison (2009) to determine if there was contagion to emerging markets from the United States. The sample period was divided into three phases: (1) February 2007 to May 2008, (2) May 2008 to September 2008, when Lehman went bankrupt, and (3) September 2008 to March 2009. The analysis of data from these time periods reveals that emerging markets had decoupled from the United States in the first period. The performance of equity, credit, and currency markets was dissimilar, with emerging assets outperforming.

In the second phase, emerging equity and currency markets fell relative to those in the United States. The credit market performance, however, was similar. In phase three, U.S. and emerging markets both experienced severe declines, suggesting a recoupling of the markets. Additionally, the correlations between the U.S. market and 9 of 11 emerging equity markets increased after August 2008.

To conclude, contagion is an issue that should be of concern to global investors given the effect of contagion on portfolio performance. Evidence indicates that contagion is predictable and results from investor wealth constraints and herding behavior. Although contagion had been declining in frequency, the recent financial crisis illustrates that it has not been eliminated.

\section{Changes from Market Integration and Liberalization}

If markets are completely integrated, then capital will flow freely across borders and assets of the same risk will provide the same expected return. Although integration and liberalization often occur concurrently and the terms are used interchangeably, they are distinct. Specifically, liberalization refers to market reforms, such as increased prosecution of insider trading, banking industry reforms, and company privatizations.

If a market is fully integrated, security prices will depend on the covariance with a global market portfolio because investors can include the country's assets in a well-diversified portfolio. At the other extreme, if a market is fully segmented, then asset prices in the developing country will depend on stand-alone risk because capital cannot flow across borders. Many emerging countries opened their markets to foreign investors in the early 1990s to attract capital and increase economic growth.

To measure the degree of integration, the ratio of investable to total market capitalization is often used. ${ }^{3}$ Alternatively, Bekaert, Harvey, Lundblad, and Siegel (2007) use the difference between local market and global industry $\mathrm{P} / \mathrm{E}$ s as a measure of integration. If there are substantial differences between the local market $\mathrm{P} / \mathrm{E}$ for an industry and the global $\mathrm{P} / \mathrm{E}$ for that same industry, then the market is characterized as less integrated.

Bekaert and Harvey (2003) and other authors delineate the effects from market integration and liberalization as reflected in stock prices, volatility, diversification benefits, market microstructure, market efficiency, cost of capital, and economic growth. 4

Equity Prices. As a market becomes integrated, stock prices usually increase as investors buy equities previously unavailable. Equity prices also increase because the covariance with world markets will be lower than the stand-alone variance of the emerging equity. As prices rise in the newly integrated market, the expected return for the market should decline given the lower covariance.

The belief that market integration and liberalization increase share prices in emerging markets is confirmed by examining the premiums for closed-end funds. Patro (2005) finds that emerging market fund prices and underlying asset prices increase after a market is liberalized.

Other studies have examined the returns for country indices and found that returns are positive for countries upon liberalization, with subsequent declines perhaps because of overly high liberalization returns. Patro and Wald (2005) report that in the 12 months surrounding liberalization, returns increase by an average of 1.5 percent per month. Three years after liberalization, returns are positive but at lower levels. In the three years starting threeand-a-half years after liberalization, returns decline by 2.88 percent per month.

\footnotetext{
3Investable stock indices reflect the availability of emerging market equity to outside investors.

4The discussion in this section uses the framework provided in Bekaert and Harvey (2003) to outline the changes from market integration and liberalization.
} 
If returns are examined for individual companies instead of country indices, the benefits of liberalization vary. In the period surrounding liberalization, only 52.4 percent of companies have higher returns and 45.8 percent have lower returns three years after liberalization. In the last period, 77.8 percent of companies have lower returns during those three years. Thus, the return benefits of liberalization are not widely shared, but the subsequent decline in returns is.

The differences in company returns from liberalization depend on company characteristics. During liberalization, smaller companies, value stocks, lower local beta stocks, and companies with low currency exposure experience higher returns. After liberalization, smaller companies, lower local beta stocks, and companies with high currency exposure experience higher returns. Companies cross-listed on international exchanges have higher returns during liberalization with subsequent lower returns. These results suggest that portfolio managers should examine company characteristics before using liberalization in a strategy.

Stock Volatility. Integration may increase return variability if greater information flow results in greater return reactivity or if speculative capital flows increase. Alternatively, there could be less deviation from fundamental value, so return variability may decline. Political risk could also decline as the government opens its markets and pursues market-oriented reforms, further lowering return volatility.

Previous research has found that integration does not affect the near-term volatility of returns. Over the long run, return variability may decline as the economy matures. This result is confirmed by Patro and Wald (2005), who find that company standard deviations decline over the longer term. Umutlu, Akdeniz, and Altay-Salih (2010) report that volatility declines after integration but that it may take up to four years to do so.

Umutlu, Akdeniz, and Altay-Salih (2010) also decompose volatility into global, local, and idiosyncratic components. Controlling for other factors and examining the relationship over different time periods, they find that liberalization reduces volatility by reducing local and idiosyncratic volatility. The evidence is consistent with integration and liberalization increasing foreign investor access and interest in emerging markets, thereby improving the accuracy of information in these markets.

Diversification Benefits. Despite their higher stand-alone risk, emerging markets offer diversification benefits because of their low correlations with the developed world. Greater integration should, however, reduce the diversification benefits from emerging markets because the markets will become more correlated with the rest of the world, which also leads to higher betas with world markets.

The results from Patro and Wald (2005) confirm that global market betas increase with integration. Driessen and Laeven (2007) report that investors located in emerging countries have seen their global diversification benefits decline over time. Although an investor in an emerging market country can still benefit by diversifying outside his or her country and region, the correlations between local and global markets have increased over time while the volatility of emerging markets has declined over time.

Other research suggests, however, that liberalization does not significantly affect correlations. Christoffersen, Chung, and Errunza (2006) study the impact of liberalization and integration at both the country and company level after controlling for macroeconomic differences across countries. Here, liberalization is defined as (1) a government's decree that the market is open to foreign investors, (2) the introduction of country funds, or (3) the listing of ADRs. At the country level, stock returns in the eight months up to liberalization and three years following liberalization are economically and statistically significantly higher. Volatilities and correlations with the MSCI World Index at the country level do not change in the two years after liberalization.

At the company level, performance differences are found for large and small companies. Large companies have large revaluation effects in the eight-month period and insignificant changes in the three-year post period. In the two years after liberalization, there are large declines in volatility and little change in correlations. Small companies have small revaluation effects in the eight-month period and higher returns in the three-year post period. In the two years after liberalization, there are small declines in volatility and decreases in correlations. These results confirm those of Patro and Wald (2005) that the benefits of liberalization depend on company characteristics. 
The link between stock market integration and the co-movement between stocks and bonds in an emerging country has also been examined. Controlling for other influences, Panchenko and $\mathrm{Wu}$ (2009) report that stock and bond returns decouple after market integration. The explanation is that as the risk premium for stocks declines (which is unrelated to bonds), the returns for stocks change independently of the returns for bonds. The decoupling may also be the result of increased liquidity and analyst coverage for stocks.

Market Microstructure and Market Efficiency. A favorable market microstructure is one in which transaction costs are low, the depth of trading volume is high, and transactions are executed quickly. A better market microstructure improves informational efficiency because in efficient markets, information must be quickly reflected in security prices.

Investors should also have confidence in the market. And to improve investor confidence, many market reforms include stricter accounting standards, greater enforcement of insider trading laws, and greater property rights. The following research provides evidence on whether liberalization results in a better microstructure and improved market efficiency.

Lagoarde-Segot (2009) examines the effects of financial reforms on the market microstructure characteristics of informational efficiency, liquidity, and volatility. The reforms examined are insider trading regulations, the automation of trading systems, and accounting standardization. The microstructure characteristics are found to be interrelated because lower liquidity results in higher volatility and less informational efficiency. Insider trading regulations improve informational efficiency. The automation of trading improves informational efficiency and liquidity but also increases volatility. The implementation of international accounting standards does not affect the market microstructure. It is also found that increased international capital flows decrease volatility but also decrease informational efficiency, possibly because these flows are speculative. In summary, the author finds that liberalization is a mixed blessing for emerging countries.

Fernandes and Ferreira (2009), however, find that insider trading regulations do not improve informational efficiency in emerging markets. Examining countries where insider trading laws are enforced for the first time, they find that analyst coverage increases and stock prices in developed countries exhibit more informativeness. But in emerging markets, there is no change in informativeness. The explanation is that insiders in emerging markets contribute greatly to the information environment, but not in developed markets. In emerging markets, insiders' information contribution cannot be replaced by analysts. Insider trading laws do, however, reduce the cost of emerging equity capital. The explanation is that investors reduce their risk premium as the problem of trading against insiders is reduced.

Liquidity should increase as a result of integration because of increased trading in the market. It is well known that investors in the developed world exhibit a home bias, whereby they invest too much in domestic securities. Thapa and Poshakwale (2010) provide evidence that illiquidity may be related to this bias. Examining three measures of liquidity, they find that emerging markets with higher transaction costs attract fewer developed world investment funds. Improvements in liquidity from liberalization should reduce this bias.

Bekaert, Harvey, and Lundblad (2007) find that the liberalization of capital markets decreases the discount for illiquidity. Additionally, the illiquidity that exists in segmented emerging markets is priced in the sense that less liquid stocks have been shown to have higher expected returns.

Another method of determining the benefits of liberalization is to examine emerging market companies that have cross-listed their stock on a foreign, developed market stock exchange. In an emerging market that has not been fully liberalized, there may be barriers to investment, such as illiquidity, poor information, weak investor protection, lax accounting standards, political risk, taxes, and restrictions on the amount of stock foreigners can own. The emerging market stock may, however, be accessible via a foreign exchange before a government begins the liberalization process. 
By buying an emerging market stock on a developed market stock exchange, the investor may gain advantages not otherwise available. For example, the foreign market may offer greater liquidity or the disclosure requirements may be stronger. In this case, the difference in pricing for the stock between the developed market and the emerging market exchange can provide insight into the benefits of liberalization and integration, based on the assumption that a listing on a foreign exchange is liberalization and integration on a small scale.

Chan, Hong, and Subrahmanyam (2008) examine differences in stock prices in the home and foreign (destination) market. The methodology compares monthly changes in the ADR premium and changes in liquidity in the home and destination market. This approach controls for such other effects as differences in corporate governance because these effects do not change over short intervals. The authors find that the premium is positively correlated with the ADR's liquidity and negatively correlated with the home market liquidity. Furthermore, this ADR premium is substantial for many companies; the premium for the most liquid ADRs is 1.53 percent higher than that for the most illiquid ADRs. It thus appears that liquidity plays a role in the reason for cross-listing in the U.S. market and that there are tangible benefits from a liberalized market.

The effect of a U.S. cross-listing on liquidity has also been examined for emerging and developed market companies by Halling, Pagano, Randl, and Zechner (2008). When developed market companies list abroad, liquidity increases in the home market, whereas for emerging market companies, it decreases. Furthermore, for companies in countries with weak insider trading protection, liquidity declines in the home market. The results are consistent with the U.S. market providing investor protection and liquidity that is not available in the domestic emerging market.

The authors also find that for emerging market companies, cross-listings have been increasing over time, whereas for developed market companies, they have been decreasing. These results suggest that liquidity and investor protection are important benefits from having a liberalized market and that many emerging markets have not yet fully integrated. 5

Results provided by Levine and Schmukler (2007) support the idea that cross-listing shifts the location of trading to the developed market. When more emerging market companies cross-list or raise capital internationally, the domestic liquidity in the internationalized companies declines and other companies in the country experience less trading.

In Latin America, Silva and Chavez (2008) report that the liquidity benefit of cross-listing depends on the size of the company and country of origin. Larger companies and Chilean companies actually have lower trading costs in the home market. Smaller companies and companies from Argentina, Brazil, and Mexico have lower trading costs in the ADR. In fact, liquidity costs in Brazil and Mexico are 2 percent higher in the home market.

Goto, Watanabe, and $\mathrm{Xu}$ (2009) provide evidence suggesting that when emerging market companies crosslist their shares in the United States, managers more fully disclose information. The effect is found to be stronger for companies that list on an exchange than for companies that cross-list in the over-the-counter markets. The effect is also found to be weaker for developed market companies that cross-list. This finding is consistent with cross-listing providing the greatest informational efficiency benefit when the home market's information environment is weaker and when that of the destination market is stronger.

Examining cross-listings by destination country, Roosenboom and van Dijk (2009) find that the announcements of U.S. listings produce the largest abnormal returns at 1.29 percent. Announcements of listings in London and Europe produce weaker returns, and the effect in Tokyo is not significant. The gains from U.S. listings are found to be attributable to the improved disclosure and investor protection in the United States. The gains from a London listing are attributed to a reduction in market segmentation and better investor protection.

Other research examines why emerging market mutual funds would hold an ADR rather than the stock in the local market. Aggarwal, Dahiya, and Klapper (2007) report that fund managers favor the U.S. ADR when the emerging country's legal protection for shareholders is weak, when the local stock market is undeveloped, and when liquidity is higher in the ADR relative to the local market. Managers are more willing to invest locally if insider trading is prosecuted.

5 Nishiotis (2006) finds that market integration is a gradual process that can be reversed. 
An expansive study of emerging market integration includes not just the shares listed on a foreign exchange but also the amount of stock available to foreign investors and the flow of U.S. investments. Using this approach, Bae, Bailey, and Mao (2006) find that when integration increases, there is less earnings management, earnings are less smooth, analysts produce more forecasts, the forecast dispersion of analysts is greater, and there are more analysts. Examining company-specific data in South Korea, the authors find that the information environment is not improved as much when corporate governance is weak.

In contrast to most research that reports generally positive benefits from cross-listings, Sarkissian and Schill (2009) report that cross-listings do not generally result in long-term valuation gains or lower costs of capital. The lack of long-term gains persists even for listings in countries with greater liquidity, greater size, or better legal protection for shareholders. There are, however, long-term gains related to improved disclosure.

Comparing trading on emerging and developed market exchanges for cross-listed stocks, de la Torre, Gozzi, and Schmukler (2007) report counterintuitive results. They find that the advent of emerging market reforms (such as the enforcement of insider trading laws, electronic trading, and privatization) shifts a greater proportion of trading to developed foreign markets possibly because local companies become more attractive to foreign investors. Although local liquidity does increase on an absolute basis, the results contradict the belief that reforms will shift proportionately more liquidity to the home market if reforms are enacted.

Cost of Capital and Economic Growth. If equity prices increase, risk decreases, and liquidity increases, the cost of capital for emerging market companies should decrease. Additionally, when a government liberalizes the economy, it reduces its interference in the economy and investors should become more willing to invest in risky assets. The expected returns and cost of capital should fall from this effect as well.

As more and cheaper capital is invested, economic growth should increase. Although some argue that foreign capital is often squandered, the evidence indicates that investment increases after liberalization while consumption stays constant. Furthermore, liberalization often increases company efficiency, perhaps because of the improved corporate governance demanded by foreign investors.

Gupta and Yuan (2009) report that the economic growth from integration and liberalization is distributed unequally across companies and industries. Those companies reliant on external financing and those with greater opportunities experience the most growth. Most of the growth from liberalization occurs from the growth of existing companies, rather than from the entry of new companies. The benefits of liberalization can be more equally shared if there are also reforms that reduce the barriers to entry in a country.

The belief that integration reduces the cost of capital is supported by analyses of mergers. Segmented companies with limited sources of capital may benefit by merging with a developed world company with a lower cost of capital. Francis, Hasan, and Sun (2008) find that when a target company is in a segmented market, the acquirer's gains are significantly higher than when the target is in an integrated country.

Furthermore, the gains are higher when the acquirer has a lower cost of capital as measured by beta and its credit rating. Longer-term operating performance post merger is significantly higher for segmented targets, relative to integrated targets, when the acquirer is a large company. Small acquirers do not experience any benefits with either type of target. Lastly, when the target is a segmented company, analysts rate growth prospects more favorably and the combined company is more likely to subsequently issue bonds and stock. This evidence suggests that there are substantial economic benefits when high costs of capital are reduced for segmented companies.

In summary, market integration and liberalization generally increase stock prices, decrease volatility, may decrease diversification benefits, improve market microstructure, increase informational efficiency, lower the cost of capital, and increase economic growth. The benefits are, by and large, confirmed in the liberalized emerging local markets as well as in the case of companies that cross-list their shares. The benefits, however, are not equally shared among all companies in the emerging country. A portfolio manager should examine company characteristics before executing strategies based on market integration and liberalization. 


\section{Return Factors}

If markets are segmented, then a country's macroeconomic conditions will be a greater influence on an emerging market company's stock return than global industry conditions. As a country becomes more integrated, global industry factors should increase in importance. In the 1990s, industry factors increased in importance in emerging markets when many countries liberalized their markets.

In developed markets, country factors have decreased in importance while industry factors have increased to the point where they are at least equally important for explaining returns. Although industry effects have been increasing over time in emerging markets, the majority of research has found that country effects still dominate global industry effects (see Bai and Green 2010; Chen, Bennett, and Zheng 2006; Puchkov, Stefek, and Davis 2005). The implication for asset allocation is that risk-averse investors should continue to diversify across emerging countries, whereas active managers should consider country characteristics in their investment strategy.

Consistent with country factors being more important than global factors in emerging markets, Conover, Jensen, and Johnson (2002) find that mean stock returns for emerging markets are generally unrelated to U.S. Federal Reserve monetary policy. This finding is in contrast to results found for developed markets in Conover, Jensen, Johnson, and Mercer (2005), where an expansive Fed policy (i.e., a global monetary policy factor) was associated with higher returns for global markets.

Research by Estrada, Kritzman, and Page (2006) finds, however, that the dominance of the country factor in emerging markets varies by region. It was found to be dominant in Asia but not in Latin America, Europe, the Middle East, and Africa. Raju and Khanapuri (2009) also find that within Asia, the country markets are not homogeneous. Some markets are integrated whereas others are more segmented, thereby providing greater diversification potential for global investors.

Country and industry effects may also differ at the company level depending on the integration of the company. Phylaktis and Xia (2006) use the level of foreign sales and an ADR listing as measures of company integration. Greater foreign sales increase global influence, decrease country influence, and result in no change in industry influence. An ADR listing increases global and industry effects and somewhat surprisingly increases country effects. Previous research is also confirmed that, compared with developed markets, country effects are higher and global and industry effects are lower in emerging markets.

The results imply that the most efficient form of diversification would be across countries in emerging markets but that the spectrum of industries should also be included because the influence of industries has increased over time. Furthermore, companies with less foreign sales and an ADR listing would provide the most efficient diversification in emerging markets.

Lastly, research by Brooks and Del Negro (2005) has shown that much of the country factor for stock returns can be accounted for by a regional factor. The implication is that investors should diversify outside their country and region to obtain efficient diversification. Regional influences on emerging market returns have not significantly declined over time.

Country-Level Return Factors. Given that country factors are generally more important than industry factors for returns, investors may want to begin their investigation in emerging markets by examining countries. Because returns in an emerging market country depend more on local factors than global factors, the choice of countries would determine a large part of performance.

Fernandes (2005) finds that emerging market integration during the 1990s resulted in reduced diversification benefits, so an allocation to a broad emerging market index does not improve the performance of a global equity portfolio. This is true for either a value-weighted or an equally weighted index. This finding implies that an investor should examine the characteristics of individual countries and not simply allocate to a broad emerging market index. 
Kortas, L'Her, and Roberge (2005) test the predictability of emerging market returns at the country level during 1996-2003 and show that the following four categories and seven variables forecasted returns:

- Fundamental: price-to-book ratio and one-year forward P/E,

- Macroeconomic: changes in the consumer price index and the quarterly growth rate of the industrial production index,

- Technical: a momentum variable (the short-term return over a six-month horizon) and a contrarian variable (the return over the past three years), and

- Country risk: Institutional Investor magazine’s Country Credit Rating.

Countries are ranked in each of the four categories. A composite score is also formed for all four categories. The strategy goes long the highest-ranked countries and short the low-ranked countries. This approach is used instead of a linear regression because emerging markets are very heterogeneous and their returns are nonnormal and unstable. Based on quarterly returns for each of the four categories, the fundamental variables provide the highest return and risk-adjusted return whereas the technical variables provide the weakest performance. The composite classification provides the highest quarterly return, at 5.8 percent.

A similar return is found when the methodology is repeated for an earlier data sample for 1986-1995. Furthermore, using the strategy in a long-only approach provides excess returns relative to an equally weighted investment in emerging markets. The results are robust to the inclusion of transaction costs, different ranking methods, and the exclusion of small and outlier countries.

The relationship between returns and country characteristics is also explored by earlier research.

Erb, Harvey, and Viskanta (1997) use data from 1985 through 1996 and report that countries with higher financial, economic, and credit risk have higher subsequent mean returns. Except for countries ranked by economic risk, the lower-risk countries also have lower variability in subsequent returns. Low-inflation countries, however, have higher mean returns and lower standard deviation in returns than high-inflation countries. Emerging market countries with lower stock market capitalization have lower returns and less risk than large-cap countries. Note that the size effect here is opposite in sign to that usually found for developed market companies.

Momentum and value effects are consistent with developed markets. High return momentum countries have higher returns but also higher risk than low momentum countries. Low price-to-book, $\mathrm{P} / \mathrm{E}$, and price-to-dividend countries have higher mean returns and lower subsequent risk than countries with high valuation attributes. 6

In addition, evidence from Desrosiers, Kortas, and L'Her (2006) shows that alpha at the country level can be earned by switching between relative-value and relative-strength strategies. The relative-value strategy goes long half the countries with the lowest price-to-book ratios and goes short the other half. The relative-strength strategy goes long the countries in the highest half of past one-year returns and goes short the other half. The portfolios are rebalanced monthly, and data are from 1995 to 2004.

The relative-value strategy is used when the past 12-month excess return for the equally weighted index is negative, and the relative-strength strategy is used when it is positive. The resulting monthly alpha is 0.78 percent and is statistically significant after controlling for the excess emerging market return, a size country factor, a relative value factor, and a momentum factor. The alpha remains positive after consideration of likely transaction costs.

Recent research by Barclay, Fletcher, and Marshall (2010) that uses data from 2002 to 2008 has found, however, that a world CAPM (capital asset pricing model) approach, where the market portfolio is a global equity index, predicts equity returns for emerging market country indices just as well as approaches that include currency risk, dividend yield, and lagged industrial production.

More generally, the evidence in Froot and Ramadorai (2008) shows that macroeconomic announcements in developed countries are important for emerging market return volatility and trading volume. Such announcements as those for production, employment, inflation, and monetary policy information in the United States and Japan are followed by increased return volatility and trading volume in South Korea and Thailand.

6Bekaert, Harvey, and Lundblad (2007), however, find that the dividend yield does not have predictive power for emerging market returns, as was found for developed markets. 
In addition to the studies that have examined whether fundamental analysis can predict country returns, a line of research examines whether technical analysis is useful. If stock returns follow a random walk, then they are not predictable using previous-period prices. If they do not, then there may be technical rules that can be used to predict future prices.

Chang, Lima, and Tabak (2004) examine 11 emerging market countries from 1991 through 2003. Returns for the emerging countries are found to be related to previous returns because autocorrelations are positive and significant at the lag one level. Technical trading rules perform best in bull markets. The profits, however, are insignificant after accounting for transaction costs and a buy-and-hold strategy. Hatgioannides and Mesomeris (2007) provide somewhat similar results using country indices from 1988 to 2002. Technical trading rules are found to provide excess profits before transaction costs in Latin American and Asian markets. But after transaction costs are considered, excess returns remain only in Asia.

Company-Level Return Factors. Other research has examined emerging market investment strategies using a company-level approach. Van der Hart, Slagter, and van Dijk (2003) use data from 1982 to 1999 to form portfolios in each emerging market country by going long the 15 percent highest-ranked stocks and going short the 15 percent lowest-ranked stocks. The examined strategies result in the following:

- Value stocks outperform growth stocks, where the characteristic is defined by the forward earnings-to-price ratio and the book-to-market ratio.

- A momentum strategy that goes long past winners and short past losers produces excess returns, where winning/losing is defined as the previous stock price performance over the past three, six, and nine months.

- Companies with positive analyst earnings revisions outperform those with negative revisions, where the variable is the number of analysts predicting an increase in earnings versus those predicting a decrease.

- A strategy that combines value, momentum, and earnings revision characteristics improves performance.

Additionally, it is also found that

- The excess returns from the strategies are not explained by risk.

- The excess returns remain significant even after controlling for the lack of liquidity, higher transaction costs, and outlier returns often found in emerging market countries, as well as a delay to strategy implementation (reflecting potential cross-border investment restrictions).

- Strategies based on size, liquidity, and mean reversion in returns do not provide excess returns.

Interestingly, the strategy's excess return and risk increase substantially when portfolios are formed globally, rather than within emerging market countries. This allows for country selection but also reduces country diversification. This finding supports the importance of the country factor for emerging market returns. It is also noteworthy that the financial liberalization of countries does not greatly affect the returns from the strategies.

In contrast to the research just discussed, analysis from Estrada and Serra (2005), based on data from 1976 through 2001, shows that size matters for company returns. Portfolios of emerging market companies in 30 countries are formed every five years based on 10 risk variables grouped into three families:

- Traditional risk variables: standard deviation, local beta, and global beta,

- Factor variables: size and book-to-market ratio (in both absolute terms and relative to the local market), and

- Downside risk variables: semideviation, local downside beta, and global downside beta.

Local variables are calculated relative to the local market, and global variables are calculated relative to the MSCI World Index.

For all variables except global beta, high-risk portfolios result in higher returns, with global downside beta providing the highest returns. If $\$ 1,000$ is invested for 20 years, a high-risk portfolio using global downside beta outperforms the low-risk portfolio by nearly $\$ 55,000$. The minimum outperformance is $\$ 1,253$ for the relative size portfolio. Note that in this company-level research, smaller size results in higher returns, in contrast to the previously discussed research at the country level. 
Other evidence using data from 1989 to 2004 has found that the price-to-book ratio and beta are not consistently priced. Girard and Rahman (2007) report a size effect, but in contrast to the results just given, larger companies have higher returns. It is also found that the political, financial, and economic risks that often limit investment in emerging markets are important for returns. Using principal component analysis, the authors calculate a composite investable risk premium that is priced in many markets.

Research at the company level by Fredericks (2005) finds that small- and mid-cap emerging market stocks have higher returns than large-cap stocks and that they also have lower correlations with developed country stocks. The explanation is that large-cap stocks are export driven with returns determined primarily by global factors, whereas small- and mid-cap stocks are affected more by local factors. For example, Samsung Electronics, one of the largest emerging market stocks, derived 70 percent of its sales outside Korea.

Whereas large-cap stocks have heavy analyst coverage, coverage is sparser for small- and mid-cap stocks. This discrepancy creates inefficiencies and presents investment opportunities but requires greater investor due diligence. Small- and mid-cap stocks also have lower levels of liquidity. Only a third of small- and mid-cap stocks had daily liquidity of $\$ 1$ million or more. They also result in more tracking error because they are a small part of emerging market indices.

Although the findings on returns in emerging markets may be the result of higher risk, it is also possible that they are caused by informationally inefficient markets. Evidence to this effect is found by van der Hart, de Zwart, and van Dijk (2005), who examine the excess returns to value, momentum, and analyst earnings revision strategies. They find that a four-factor asset-pricing model, including market, book-to-market, size, and momentum factors, cannot explain the excess returns.

Note though that some of the return differentials may not be exploitable because of the higher costs of trading in emerging markets and limitations on investability. Furthermore, the nonnormal return distribution of emerging market returns suggests that returns should not be evaluated solely in a mean-variance framework.

More generally, Tokat and Wicas (2004) delineate the limitations to using emerging market data for analysis. First, the performance record for emerging markets is typically quite short and based on a limited amount of data. Second, the emerging market database can change dramatically in composition as countries liberalize their capital markets. For example, from 1988 to 2003, the number of emerging markets increased from 9 to 33. Third, there is a selection bias in that the countries and companies in an emerging market database are those that have been successful (i.e., they meet minimum size and liquidity requirements). This creates an upward bias in the returns.

In sum, the evidence at the country level suggests that, in general, returns are related to beta, country risk, macroeconomic, momentum, and value characteristics. At the company level, returns are related to analyst earnings revisions, various beta measures, momentum, standard deviation, and value characteristics. The evidence for company size is unclear as to its significance and sign. There is also evidence that some of the return patterns cannot be fully explained by risk; however, the limitations of emerging market data imply that investors should proceed with caution before using these investment strategies.

\section{Institutional Investor and Analyst Performance}

Several studies examine the performance of institutional investors and analysts in emerging markets. Given the potential inefficiencies in emerging markets, it is possible that better capitalized and informed investors would earn excess returns.

Froot and Ramadorai (2008) find that cross-border capital flows, from U.S. institutional investors to emerging markets, predict emerging market equity returns and the returns to emerging market equity closed-end funds. The results indicate that foreign investors may perform better than domestic investors.

Other evidence, however, by Teo (2009) indicates that a local presence for hedge funds improves performance. Hedge funds with a physical presence in a country experience stronger risk-adjusted returns than those funds without such, and this finding is especially true for emerging market hedge funds. This effect is still present after controlling for fees, serial correlation, and biases in data. Also interesting is that native-speaking fund managers 
outperform non-native speakers. It appears that distant funds may trade performance for better access to capital. Funds that are more distant to their asset location can charge more fees, raise more capital, and set longer redemption periods.

This research is also consistent with that from Bae, Stulz, and Tan (2008), who find that local analysts estimate earnings more accurately than foreign analysts, especially in emerging markets where there may be information barriers. Research by Chang (2010) differentiates the nationality of analysts even finer. In addition to local and foreign analysts, expatriate analysts are defined as foreign analysts with a local presence. It is found that in the Taiwanese market, expatriate analyst recommendations outperform those of local and foreign analysts. The difference between local and expatriate performance is attributed to a difference in resources, whereas the difference between foreign and expatriate performance is attributed to location. It also appears that institutional investors trade on information from expatriate analysts and ignore the recommendations of other analysts.

The majority of emerging market equity issues are brought to market by local underwriters. Lai and Teo (2008) thus hypothesize that local analysts in emerging markets exhibit a "home bias," where they are overly optimistic for local company prospects relative to foreign analysts. Because of this bias, their equity upgrades underperform foreign analyst upgrades and their downgrades outperform foreign analyst downgrades (e.g., if typically optimistic local analysts are pessimistic, the company must be particularly troubled).

These results persist after controlling for country, time period, size, and value/growth characteristics. Furthermore, local analysts are more optimistic on a relative basis when the local market is hot and when more issues are underwritten by local underwriters. Interestingly, foreign investors overestimate the bias of foreign recommendations whereas local institutional investors underestimate the bias in local recommendations.

Gottesman and Morey (2007) examine the performance of institutional investors and find that emerging market mutual funds underperform passive indices and that the only predictor for fund performance is the expense ratio. Lower ratios predicted better fund performance. The evidence suggests that a low-cost index fund may be the best mutual fund investment.

Eling and Faust (2010) compare emerging market mutual funds with hedge funds and find that hedge funds outperform mutual funds. Hedge fund outperformance occurs in bear and neutral markets, whereas their performance during bull markets is similar to that of mutual funds. The better performance of hedge funds appears to be a result of their flexibility in shifting asset allocations. The authors also confirm that mutual funds do not generally outperform traditional benchmarks.

Douglas (2009) reports that, comparing hedge funds with an index, emerging market hedge funds provide considerably less downside risk. Compared with developed world hedge funds, emerging market hedge funds usually use less leverage, resulting in less-extreme losses. This finding is consistent with research by Abugri and Dutta (2009), who found that emerging market hedge funds outperform indices when measured with a modified

Sharpe ratio. The outperformance, however, is not statistically significant. It was also determined that emerging market hedge funds are increasingly behaving more like developed world hedge funds.

In sum, it appears that analysts with a local presence produce better stock recommendations, with the results differing based on nationality and whether the recommendation is an upgrade or downgrade. Emerging market mutual funds do not outperform indices, whereas hedge funds do.

\section{Currency Issues}

Currency issues are a concern because currency depreciation reduces the return in the investor's domestic currency terms. Furthermore, emerging market governments often purposely devalue their currency and restrict its convertibility, which prevents foreign investors from repatriating their investment back to their domestic currency.

Solnik and McLeavey (2009) note that in developed countries, the correlation between currency changes and stock returns is often negative because a depreciating currency makes the country's exports less expensive to foreign consumers. When currencies depreciate, exporters' earnings and stock prices increase. Currency and stock risk, therefore, often offset one another, reducing the risk to a foreign investor. 
This relationship traditionally was not the case in emerging markets, where stock returns and currency changes were often positively correlated. During crisis periods, both emerging market currencies and stocks declined in value as investors lost faith in emerging market countries. The emerging market stockholder would experience losses on both the stock and currency position.

Recent research, however, suggests that the relationship between currency changes and stock prices in emerging markets has changed. Chue and Cook (2008) examine the relationship for two periods: 1992-2002 and 2002-2006. In the earlier period, stock prices declined when the currency declined, as expected. This result is attributed to excessive levels of debt denominated in dollars, where a weaker domestic currency makes the repayment of dollar debt more expensive for a country.

In the latter period, however, stock prices increased when the currency declined, as in developed markets. This latter result is consistent with emerging market companies using their local debt markets and currency derivatives to a greater degree.

Currency risk is partly a function of a country's exchange rate regime (e.g., freely floating, fixed, managed float, pegged). As DeRosa (2009) points out, however, a country's stated exchange rate policy is not a reliable indicator of a currency's future path for several reasons. First, in many countries, there are also black or parallel markets for a country's currency, where the currency valuation is different from the official rate. Second, a country's stated exchange rate regime is often different from the one actually practiced. For example, during the "pegged" era of Bretton Woods, many currencies were in fact freely floating. Third, "freely falling regimes," which are characterized as having annual inflation rates greater than 40 percent, were present in 41 percent of transitional economies during the 1990s. ${ }^{7}$ Fourth, a government's stated exchange rate regime changes over time. In one year alone from 2005 to 2006, 25 developing countries changed their exchange rate regimes.

If a country tries to peg its currency while pursuing expansive fiscal and monetary policies, its currency can be subject to speculative attack. Emerging market currency crises are not uncommon. From 1994 to 2002, 10 emerging market countries experienced currency crises, starting with Mexico and ending with Argentina. These include the heralded BRIC (Brazil, Russia, India, and China) countries of Russia (1998) and Brazil (1999). Compounding an emerging market crisis is the fact that the foreign debt of emerging markets is often denominated in a hard currency. 8 As the domestic currency declines in value, the government finds its foreign debt repayment more expensive in domestic currency terms. After Mexico's currency crisis, its foreign debt increased by 75 percent in peso terms.

Research by Kaminsky (2006) finds that currency crises in emerging economies are triggered by multiple vulnerabilities, such as financial excess, fiscal deficits, current account deficits, and sovereign debt problems. In contrast, crises caused solely by global shocks and crises in countries with immaculate fundamentals are found only in mature markets. In total, 86 percent of emerging crises are those with multiple domestic problems, whereas economic weakness characterizes only 50 percent of mature market crises. It was also found that crises from financial excesses have the highest costs and crises from debt problems have the second highest costs.

According to Cumperayot, Keijzer, and Kouwenberg (2006), currency contagion is usually contained within a region but stock market crashes are usually more global, especially when emanating from the United States. Furthermore, extreme currency depreciations often follow extreme stock market declines on the same day. The opposite, however, is not true (i.e., extreme currency losses are not typically followed by large stock declines).

Kumar, Moorthy, and Perraudin (2003) find that currency crashes are predictable to the extent that trading profits can be made. Crashes are defined in absolute terms as currency depreciations greater than 5 percent or 10 percent and relative to that expected from interest rates. The variables most significant for predicting currency crashes are changes in foreign currency reserves, real GDP changes, and a regional contagion dummy. Other variables that contribute to a lesser extent are currency reserves relative to imports, portfolio investments in the country, debt levels, and the lagged exchange rate. The resulting U.S. dollar profits are approximately 50 bps per trade, which should be economically significant in the liquid markets examined.

\footnotetext{
7 A transitional economy is one transitioning from a centrally controlled economy to a free market economy.

8DeRosa (2009) notes that when emerging governments borrow to the local capital market's capacity, they will turn to the greater pool of global capital. Because the lenders will usually want to be paid back in U.S. dollars, the government incurs foreign exchange risk.
} 
There is also evidence that currency movements can be predicted during noncrisis periods using fundamental and technical trading rules. The fundamental analysis of de Zwart, Markwat, Swinkels, and van Dijk (2009) overweights currencies with high real interest rates and high GDP growth rates. Moving average rules as well as support and resistance rules are used in the technical analysis. When used individually, the fundamental and technical trading rules generate economically and statistically significant Sharpe ratios. When used together, the Sharpe ratios are improved further still. In addition, the consistency of performance is better across currencies. Lastly, the strategies perform better for emerging market currencies, versus developed currencies alone.

Frankel and Poonawala (2010) report that the forward rate is a better predictor of the future spot rate in emerging market currencies than it is in developed markets because the forward rate bias is smaller in emerging markets. It is also usually positive, which suggests that a carry trade should go long the developed world currency and short the emerging market currency.

In summary, evidence indicates that the historically positive correlation between emerging market stocks and currencies has turned negative. Currency crises can be severe and contagious for emerging markets and appear to be predictable. Currency strategies have generated economically and statistically significant profits in emerging markets.

\section{Conclusion}

Given their potentially high returns and low correlations, emerging market investments can benefit developed world portfolios. Investors should, however, be aware of the nonnormal returns, corporate governance issues, contagion, currency issues, and the changes in these markets from integration and liberalization. Although emerging markets have been converging to developed markets because of integration and liberalization, equity returns are still primarily influenced by a country factor. Evidence suggests that strategies based on country factors, company characteristics, and currencies have provided excess returns. Also of investor interest, the performance of institutional investors and analysts has been shown to vary by location and type. The uniqueness and newness of these markets have implications for the use of data. Investors should understand these limitations and the risks unique to emerging economies, markets, and currencies.

This publication qualifies for 1 CE credit. 


\section{References}

Abugri, Benjamin A., and Sandip Dutta. 2009. "Emerging Market Hedge Funds: Do They Perform Like Regular Hedge Funds?" Journal of International Financial Markets, Institutions and Money, vol. 19, no. 5 (December):834-849.

Using a modified Sharpe ratio, the authors find that emerging market hedge funds outperform emerging market equity indices. The outperformance, however, is not statistically significant. Additionally, it appears that emerging market hedge funds are increasingly behaving like developed world hedge funds.

Aggarwal, Reena, Sandeep Dahiya, and Leora Klapper. 2007. "ADR Holdings of US-Based Emerging Market Funds.” Journal of Banking E Finance, vol. 31, no. 6 (June):1649-1667.

Emerging market mutual funds would rather hold an ADR than the stock in the local market if the country's legal protection is weak, when insider trading is not prosecuted, and if the local stock market is undeveloped or less liquid. Data are for 111 funds in 2002.

Aggarwal, Reena, Leora Klapper, and Peter D. Wysocki. 2005. "Portfolio Preferences of Foreign Institutional Investors." Journal of Banking E Finance, vol. 29, no. 12 (December):2919-2946.

The authors examine the holdings of emerging market mutual funds in 2002 for 30 emerging market companies. Mutual fund managers prefer companies with ADRs and more transparent accounting as well as countries with superior accounting standards, legal systems, and shareholder protections.

Bae, Kee-Hong, Warren Bailey, and Connie X. Mao. 2006. "Stock Market Liberalization and the Information Environment." Journal of International Money and Finance, vol. 25, no. 3 (April):404-428.

Data from 1986 to 2002 indicate that a financial market more open to foreign investment results in an improved information environment. Evidence also indicates that this improvement is muted when a company's corporate governance is weak.

Bae, Kee-Hong, Chanwoo Lim, and K.C. John Wei. 2006. "Corporate Governance and Conditional Skewness in the World's Stock Markets.” Journal of Business, vol. 79, no. 6 (November):2999-3028.

Using data on 18 emerging market countries from 1995 to 2003, the authors find that positively skewed returns are more common when a company is part of a family of companies and when governance is poor.

Bae, Kee-Hong, Rene Stulz, and Hongping Tan. 2008. "Do Local Analysts Know More? A Cross-Country Study of the Performance of Local Analysts and Foreign Analysts." Journal of Financial Economics, vol. 88, no. 3 (June):581-606.

In 32 countries, local analysts provide more accurate estimates than foreign analysts, especially in emerging markets.

Bai, Ye, and Christopher J. Green. 2010. "International Diversification Strategies: Revisited from the Risk Perspective." Journal of Banking E Finance, vol. 34, no. 1 (January):236-245.

Although industry effects have been increasing over time, country effects still dominate in emerging markets. The data used are from 13 emerging markets and 11 industries from 1984 to 2004. 
Barclay, Richard, Jonathan Fletcher, and Andrew Marshall. 2010. "Pricing Emerging Market Stock Returns: An Update." Emerging Markets Review, vol. 11, no. 1 (March):49-61.

The authors use data from 1995 to 2008 to describe the cross-sectional distribution of emerging market equity returns at the country level. They find that a world CAPM model predicts emerging market returns just as well as models that include currency risk, dividend yield, and lagged industrial production.

Bekaert, Geert, and Campbell R. Harvey. 2003. "Emerging Markets Finance." Journal of Empirical Finance, vol. 10, no. 1-2 (February):3-55.

The authors provide a survey of the literature in emerging markets and an overview of issues relevant for investors.

Bekaert, Geert, Campbell R. Harvey, and Christian Lundblad. 2007. "Liquidity and Expected Returns: Lessons from Emerging Markets.” Review of Financial Studies, vol. 20, no. 6 (November):1783-1831.

The authors use the number of zero-return days as a measure of illiquidity and find that less liquid emerging market stocks have higher future returns.

Bekaert, Geert, Campbell R. Harvey, Christian Lundblad, and Stephan Siegel. 2007. "Global Growth Opportunities and Market Integration.” Journal of Finance, vol. 62, no. 3 (June):1081-1137.

The authors find that global industry $\mathrm{P} /$ Es better predict a country's future economic growth than local P/Es. They also use the difference between global industry $\mathrm{P} / \mathrm{Es}$ and local industry $\mathrm{P} / \mathrm{Es}$ as a measure of a country's economic integration.

Boyer, Brian H., Tomomi Kumagai, and Kathy Yuan. 2006. "How Do Crises Spread? Evidence from Accessible and Inaccessible Stock Indices.” Journal of Finance, vol. 61, no. 2 (April):957-1003.

The authors examine the 1997 Asian crisis and find that investor wealth liquidations, not market fundamentals, were responsible for the contagion between markets.

Bris, A., and C. Cabolis. 2008. "The Value of Investor Protection: Evidence from Cross-Border Mergers." Review of Financial Studies, vol. 21, no. 2 (April):605-648.

Research shows that target shareholder excess returns increase when a controlling acquirer is located in a country with better shareholder protection and accounting standards.

Brooks, Robin, and Marco Del Negro. 2005. "Country versus Region Effects in International Stock Returns." Journal of Portfolio Management, vol. 31, no. 4 (Summer):67-72.

The data are for 42 developed and emerging markets from 1985 to 2003. The results imply that investors should diversify outside their region to obtain global diversification.

Bunda, Irina, A. Javier Hamann, and Subir Lall. 2009. "Correlations in Emerging Market Bonds: The Role of Local and Global Factors.” Emerging Markets Review, vol. 10, no. 2 (June):67-96.

Data for the period 1997-2008 are analyzed for evidence of contagion. The authors find that an extended period of low correlations in emerging market bonds ended in 2008 with the collapse of Lehman Brothers.

Chan, Justin S.P., Dong Hong, and Marti G. Subrahmanyam. 2008. "A Tale of Two Prices: Liquidity and Asset Prices in Multiple Markets.” Journal of Banking E Finance, vol. 32, no. 6 (June):947-960.

The authors use a sample of 401 ADRs from 23 countries to demonstrate that increased liquidity is an important reason for cross-listing on U.S. exchanges. 
Chan, Kalok, and Allaudeen Hameed. 2006. "Stock Price Synchronicity and Analyst Coverage in Emerging Markets.” Journal of Financial Economics, vol. 80, no. 1 (April):115-147.

The $R^{2}$ in emerging market stock returns are compared with analyst activity. Using data from 25 emerging countries from 1993 to 1999, the authors find that greater analyst coverage increases the synchronicity of stock prices in emerging markets, which supports the hypothesis that analysts are producing primarily marketwide information.

Chandar, Nandini, Dilip K. Patro, and Ari Yezegel. 2009. “Crises, Contagion and Cross-Listings.” Journal of Banking E Finance, vol. 33, no. 9 (September):1709-1729.

Five currency crises are examined between 1994 and 2002. Contagion does not appear to be caused by the cross-listing of shares.

Chang, Charles. 2010. "Information Footholds: Isolating Local Presence as a Factor in Analyst Performance and Trading." Journal of International Money and Finance, vol. 29, no. 6 (October):1094-1107.

Using data for the Taiwanese stock market from 1998 to 2002, the author finds that expatriate analyst (foreigners with a local presence) recommendations outperform local and foreign analysts.

Chang, Eui Jung, Eduardo José Araújo Lima, and Benjamin Miranda Tabak. 2004. "Testing for Predictability in Emerging Equity Markets.” Emerging Markets Review, vol. 5, no. 3 (September):295-316.

Technical trading rules do not provide significant trading profits in emerging markets after consideration of transaction costs and a buy-and-hold strategy.

Chari, Anusha, Paige P. Ouimet, and Linda L. Tesar. 2010. “The Value of Control in Emerging Markets.” Review of Financial Studies, vol. 23, no. 4 (April):1741-1770.

Using data for acquisitions of emerging market companies from 1986 to 2006, the authors find that improved corporate governance results in gains to developed world acquirers.

Chen, Jianguo, Andrea Bennett, and Ting Zheng. 2006. "Sector Effects in Developed vs. Emerging Markets." Financial Analysts Journal, vol. 62, no. 6 (November/December):40-51.

The authors find that in developed markets, sector effects have caught up with country effects. In emerging markets, however, country effects have remained dominant over sector effects. Portfolio managers should emphasize sector-based approaches when investing in developed countries but use country-based strategies in emerging markets.

Chiang, Thomas C., and Dazhi Zheng. 2010. “An Empirical Analysis of Herd Behavior in Global Stock Markets.” Journal of Banking E Finance, vol. 34, no. 8 (August):1911-1921.

Daily data are used for advanced and emerging markets from 1988 to 2009. The authors find that herding behavior increases during crisis periods, which increases contagion.

Christoffersen, Peter, Hyunchul Chung, and Vihang Errunza. 2006. "Size Matters: The Impact of Financial Liberalization on Individual Firms." Journal of International Money and Finance, vol. 25, no. 8 (August):1296-1318.

The authors use data from 1976 to 1999 for 12 emerging markets and demonstrate significant differences in performance for large and small companies as a result of liberalization.

Chue, Timothy K., and David Cook. 2008. "Emerging Market Exchange Rate Exposure." Journal of Banking E̋ Finance, vol. 32, no. 7 (July):1349-1362.

Data for 15 emerging market countries are examined for two periods: 1992-2002 and 2002-2006.

The relationship between currency changes and stock prices in emerging markets has changed over time. Most recently, emerging stock prices generally increase when the currency declines. 
Conover, C. Mitchell, Gerald R. Jensen, and Robert R. Johnson. 2002. "Emerging Markets: When Are They Worth It?” Financial Analysts Journal, vol. 58, no. 2 (March/April):86-95.

Using 24 years of data and 20 emerging market country indices, the authors find that the inclusion of emerging market equities increases portfolio returns by approximately 1.5 percent per year. The benefits of investing in emerging markets accrue almost entirely during periods of restrictive U.S. monetary policy. During expansive U.S. monetary policy periods, the benefits of holding emerging market equities are trivial.

Conover, C. Mitchell, Robert Miller, and Andrew Szakmary. 2008. "The Timeliness of Accounting Disclosures in International Security Markets." International Review of Financial Analysis, vol. 17, no. 5 (December):849-869.

The authors find that financial reporting differs systematically between common law and code law countries. In code law countries, the time taken and allowed for filing is usually longer and the statutory requirement is more frequently violated.

Conover, C. Mitchell, Gerald R. Jensen, Robert R. Johnson, and Jeffrey M. Mercer. 2005. "Is Fed Policy Still Relevant for Investors?” Financial Analysts Journal, vol. 61, no. 1 (January/February):70-79.

The authors use 38 years of data to show that U.S. monetary policy has had, and continues to have, a strong relationship with developed world security returns. Stock returns are consistently higher and less volatile during periods when the Federal Reserve is following an expansive monetary policy than during a restrictive period. The influence of U.S. monetary policy is shown to be a global phenomenon.

Cumperayot, Phornchanok, Tjeert Keijzer, and Roy Kouwenberg. 2006. "Linkages between Extreme Stock Market and Currency Returns." Journal of International Money and Finance, vol. 25, no. 3 (April):528-550.

Using data from 1995 through 2005 for 26 countries, the authors find that extreme local stock market declines predict currency declines but not vice versa. They also find that currency declines spill over to other countries in a region but not outside the region.

de la Torre, Augusto, Juan Carlos Gozzi, and Sergio L. Schmukler. 2007. "Stock Market Development under Globalization: Whither the Gains from Reforms?” Journal of Banking E Finance, vol. 31, no. 6 (June):1731-1754.

Data for market reforms from 1975 to 2004 are used to examine the effect of domestic market reforms on domestic and international stock market liquidity.

DeRosa, David F. 2009. Central Banking and Monetary Policy in Emerging-Markets Nations. Charlottesville, VA: Research Foundation of CFA Institute.

This book provides a comprehensive treatment of monetary policy and currency regimes in emerging markets.

Desrosiers, Stephanie, Mohamed Kortas, and Jean-Francois L'Her. 2006. "Style Timing in Emerging Markets." Journal of Investing, vol. 15, no. 4 (Winter):29-37.

Data are from 1995 to 2004 for 26 emerging market indices. Positive alpha is found when switching between relative-value and relative-strength strategies for country indices.

de Zwart, Gerben, Thijs Markwat, Laurens Swinkels, and Dick van Dijk. 2009. "The Economic Value of Fundamental and Technical Information in Emerging Currency Markets." Journal of International Money and Finance, vol. 28, no. 4 (June):581-604.

The authors use data for 21 emerging markets from 1997 to 2007 and demonstrate the utility of fundamental and technical trading rules for currency changes. They find that combining both provides higher profits than using them individually. Nondeliverable forward contracts are used when the currency is not freely traded. 
Dooley, Michael, and Michael Hutchison. 2009. "Transmission of the U.S. Subprime Crisis to Emerging Markets: Evidence on the Decoupling-Recoupling Hypothesis." Journal of International Money and Finance, vol. 28, no. 8 (December):1331-1349.

The coupling of the U.S. market and 14 emerging markets is examined for the period February 2007 to March 2009. It appears the markets had decoupled until 2008 but recoupled during the downturn in U.S. markets.

Douglas, Peter. 2009. "Emerging Markets: Sorting through a World of Opportunities." CFA Institute Conference Proceedings Quarterly, vol. 26, no. 3 (September):77-80.

Emerging market hedge funds have less downside risk than an index and have less leverage than developed world hedge funds.

Driessen, Joost, and Luc Laeven. 2007. "International Portfolio Diversification Benefits: Cross-Country Evidence from a Local Perspective.” Journal of Banking E Finance, vol. 31, no. 6 (June):1693-1712.

The benefits for developing country investors from regional and global diversification are substantial but have declined over time. Data are from 1985 to 2002 for 29 developing countries.

Eling, Martin, and Roger Faust. 2010. "The Performance of Hedge Funds and Mutual Funds in Emerging Markets.” Journal of Banking E Finance, vol. 34, no. 8 (August):1993-2009.

The results demonstrate that emerging market hedge funds outperform mutual funds. Data from 1995 to 2008 and six measures are used to determine performance.

Erb, Claude, Campbell Harvey, and Tadas Viskanta. 1997. "The Cross-Sectional Determinants of Emerging Equity Market Returns." In Quantitative Investing for the Global Markets. Edited by Peter Carman. Chicago: Glenlake Publishing, 221-272.

The authors examine the characteristics and factors for emerging market returns at the country level using data from 1985 through 1996.

Estrada, Javier. 2009. “Black Swans in Emerging Markets.” Journal of Investing, vol. 18, no. 2 (Summer):50-56.

The author examines 110,000 daily returns for 16 emerging stock markets and finds that outlier returns have a large impact on an investor's terminal value. The results suggest that timing the emerging markets would be extremely difficult.

Estrada, Javier, and Ana Paula Serra. 2005. "Risk and Return in Emerging Markets: Family Matters." Journal of Multinational Financial Management, vol. 15, no. 3 (July):257-272.

The authors examine the relationship between company risk and return in emerging markets for more than 1,600 companies in 30 countries from 1976 through 2001.

Estrada, Javier, Mark Kritzman, and Sébastien Page. 2006. “Markets: A Normative Portfolio Approach.” Journal of Investing, vol. 15, no. 4 (Winter):19-28.

The authors examine the relative influence of country and industry effects and find that it varies by emerging market region.

Eun, Cheol S., and Jinsoo Lee. 2010. "Mean-Variance Convergence around the World.” Journal of Banking E Finance, vol. 34, no. 4 (April):856-870.

Using data for 14 emerging markets during the period 1989 to 2007, the authors show that emerging markets have been converging to developed markets. 
Fan, Joseph P.H., and T.J. Wong. 2005. "Do External Auditors Perform a Corporate Governance Role in Emerging Markets? Evidence from East Asia." Journal of Accounting Research, vol. 43, no. 1 (March):35-72.

Hiring a Big 5 auditor in emerging markets signals that the company's financial statements are of high quality.

Fernandes, Nuno. 2005. "Portfolio Disaggregation in Emerging Market Investments." Journal of Portfolio Management, vol. 31, no. 2 (Winter):41-49.

The use of data from 1988 through 2001 demonstrates that the addition of a broad emerging market index does not appear to improve the performance of a global equity portfolio.

Fernandes, Nuno, and Miguel A. Ferreira. 2008. "Does International Cross-Listing Improve the Information Environment.” Journal of Financial Economics, vol. 88, no. 2 (May):216-244.

Controlling for ownership, liquidity, and accounting quality differences, the authors find that crosslisted emerging market companies have less stock price informativeness because of higher analyst coverage. Data are for 21,000 companies from more than 40 countries during the period 1980 to 2003.

—. 2009. "Insider Trading Laws and Stock Price Informativeness." Review of Financial Studies, vol. 22, no. 5 (May):1845-1887.

The enforcement of insider-trading laws does not increase stock price informativeness in emerging markets, although the cost of emerging equity capital is reduced. Data are for 48 countries from 1980 to 2003.

Ferreira, Miguel A., and Paulo M. Gama. 2007. "Does Sovereign Debt Ratings News Spill Over to International Stock Markets?” Journal of Banking E Finance, vol. 31, no. 10 (October):3162-3182.

The authors examine the effect of sovereign bond rating changes on equity markets in other countries and find an asymmetric spillover effect where downgrades result in lower equity returns in other countries but upgrades are not related to changes in other equity market values.

Francis, Bill B., Iftekhar Hasan, and Xian Sun. 2008. "Financial Market Integration and the Value of Global Diversification: Evidence for US Acquirers in Cross-Border Mergers and Acquisitions.” Journal of Banking E。 Finance, vol. 32, no. 8 (August):1522-1540.

Examining U.S. acquirers for the period 1996 to 2003, the authors find that gains accrue if the target is from a segmented market. The explanation is that companies in segmented markets have higher costs of capital than companies in integrated markets and the merger results in a less-expensive capital source.

Frankel, Jeffrey, and Jumana Poonawala. 2010. "The Forward Market in Emerging Currencies: Less Biased than in Major Currencies." Journal of International Money and Finance, vol. 29, no. 3 (April):585-598.

The forward rate bias is smaller in emerging markets than it is in developed markets. Fourteen emerging currencies are examined from 1996 to 2004.

Fredericks, Michael J. 2005. "Beyond the Big 50-Opportunities in Emerging Markets." Journal of Investing, vol. 14, no. 1 (Spring):24-31.

Using data from 1994 through 2004, the author reports that small- and mid-cap emerging market stocks have higher returns and lower correlations with developed country stocks than with large-cap stocks. 
Froot, Kenneth A., and Tarun Ramadorai. 2008. "Institutional Portfolio Flows and International Investments." Review of Financial Studies, vol. 2, no. 2 (April):937-971.

Cross-border capital flows, from U.S. institutional investors to emerging markets, predict emerging equity and emerging equity closed-end fund returns. The results indicate that foreign investors may perform better than domestic investors.

Girard, Eric C., and Hamid Rahman. 2007. "Capital Control Premium and Investable Risk in Emerging Capital Markets.” Journal of Investing, vol. 16, no. 4 (Winter):117-128.

An investable risk premium and a size risk premium are found to be priced in many emerging markets.

Larger companies, however, have higher returns. The price-to-book ratio and beta are not consistently priced. Data are for 26 countries from 1989 to 2004.

Goetzmann, William N., Lingfeng Li, and K. Geert Rouwenhorst. 2005. "Long-Term Global Market Correlations." Journal of Business, vol. 78, no. 1 (January):1-38.

Using 150 years of equity data, the authors show that emerging markets provide diversification by expanding the number of markets that can be invested in and offering lower correlations.

Goto, Shingo, Masahiro Watanabe, and Yan Xu. 2009. "Strategic Disclosure and Stock Returns: Theory and Evidence from US Cross-Listing.” Review of Financial Studies, vol. 22, no. 4 (April):1585-1620.

Emerging companies that cross-list their shares in the United States more fully disclose information. Data are from 1983 to 2003 for 57 companies in 12 emerging market countries.

Gottesman, Aron A., and Matthew R. Morey. 2007. "Predicting Emerging Market Mutual Fund Performance." Journal of Investing, vol. 16, no. 3 (Fall):111-122.

Emerging market mutual funds underperformed passive indices. The only predictor of fund performance was the expense ratio. Out-of-sample tests from 1997 to 2005 are used that adjust for survivorship bias.

Gupta, Nandini, and Kathy Yuan. 2009. “On the Growth Effect of Stock Market Liberalizations.” Review of Financial Studies, vol. 22, no. 11 (November):4715-4752.

The benefits of liberalization are greatest for those companies reliant on external finance and those with greater growth opportunities. Most growth comes from existing companies. Data are from 1981 to 1998 for 31 countries.

Halling, Michael, Marco Pagano, Otto Randl, and Josef Zechner. 2008. "Where Is the Market? Evidence from Cross-Listings in the United States.” Review of Financial Studies, vol. 21, no. 2 (April):725-761.

Examining foreign companies that cross-listed their shares on U.S. exchanges from 1980 to 2001, the authors find evidence consistent with emerging market companies listing in order to generate greater liquidity and investor protection.

Hatgioannides, John, and Spyros Mesomeris. 2007. "On the Returns Generating Process and the Profitability of Trading Rules in Emerging Capital Markets.” Journal of International Money and Finance, vol. 26, no. 6 (October):948-973.

Excess profits using technical trading rules are found for Asian markets. Stock index data tested are for four Latin American and four Asian countries from 1988 to 2002. 
Jin, Li, and Stewart C. Myers. 2006. " $R$ 2 around the World: New Theory and New Tests." Journal of Financial Economics, vol. 79, no. 2 (February):257-292.

The authors use data from 1990 to 2001 for 40 countries and show that company opaqueness increases the $R^{2}$ s within stock markets and the frequency of large stock price declines. This finding refines previous research that argued that poor investor protection was the cause of high $R^{2} \mathrm{~s}$ in emerging markets. The previous research argued that poor protection made company-specific information less useful to informed traders, thus increasing the proportion of noise traders relative to informed traders.

Kaminsky, Graciela L. 2006. “Currency Crises: Are They All the Same?” Journal of International Money and Finance, vol. 25, no. 3 (April):503-527.

The author examines currency crises for 20 industrial and developing countries from 1970 to 2002 and finds that emerging market currency crises are usually caused by multiple problems.

Kortas, Mohamed, Jean-Francois L'Her, and Mathieu Roberge. 2005. "Country Selection of Emerging Equity Markets: Benefits from Country Attribute Diversification.” Emerging Markets Review, vol. 6, no. 1 (April):1-19.

Examining returns for subperiods 1986-1995 and 1996-2003, the authors find that ranking emerging market countries on the basis of fundamental, macroeconomic, technical, and country risk classifications provides substantial risk-adjusted returns. There are 23 countries and seven variables examined.

Kumar, Mohan, Uma Moorthy, and William Perraudin. 2003. "Predicting Emerging Market Currency Crashes." Journal of Empirical Finance, vol. 10, no. 4 (September):427-454.

Currency crashes generate trading profits using lagged variables and data from 1985 to 1999 for 32 developing countries. A logit model is estimated in-sample using local and global financial and macroeconomic data. It is then used to generate out-of-sample forecasts and trading profits. The variables most significant for predicting currency crashes are changes in foreign currency reserves, real GDP changes, and a regional contagion dummy.

Lagoarde-Segot, Thomas. 2009. "Financial Reforms and Time-Varying Micro Structures in Emerging Equity Markets." Journal of Banking \& Finance, vol. 33, no. 10 (October):1755-1769.

The effects of insider trading regulation, the automation of trading systems, and accounting standardization on emerging market informational efficiency, liquidity, and volatility are examined. Data are from 1996 to 2007 for 28 emerging markets.

Lai, Sandy, and Melvyn Teo. 2008. "Home-Biased Analysts in Emerging Markets." Journal of Financial and Quantitative Analysis, vol. 43, no. 03 (September):685-716.

Analysts in emerging markets are overly optimistic for local company prospects relative to foreign analysts. Their equity upgrades underperform foreign analyst upgrades, and their downgrades outperform foreign analyst downgrades. Data are from 1994 to 2003 for eight emerging Asian countries.

Levine, Ross, and Sergio L. Schmukler. 2007. "Migration, Spillovers, and Trade Diversion: The Impact of Internationalization on Domestic Stock Market Activity." Journal of Banking E Finance, vol. 31, no. 6 (June):1595-1612.

Liquidity declines in an emerging equity market when more companies cross-list or raise capital internationally. The data are for 55 emerging markets for the years 1989 to 2000.

Markwat, Thijs, Erik Kole, and Dick van Dijk. 2009. "Contagion as a Domino Effect in Global Stock Markets." Journal of Banking E Finance, vol. 33, no. 11 (November):1996-2012.

The authors find that global crises are preceded by regional and local crises, with interest rates, stock volatility, and bond returns also predicting returns. Data are daily from 1996 to 2007. 
Morey, Matthew, Aron Gottesman, Edward Baker, and Ben Godridge. 2009. "Does Better Corporate Governance Result in Higher Valuations in Emerging Markets? Another Examination Using a New Data Set." Journal of Banking E' Finance, vol. 33, no. 2 (February):254-262.

The authors examine changes in corporate governance in emerging market companies and find that improvements are related to increases in company value.

Nishiotis, George P. 2006. "Further Evidence on Closed-End Country Fund Prices and International Capital Flows.” Journal of Business, vol. 79, no. 4 (July):1727-1754.

The author examines data for 10 emerging markets and finds that market integration is a gradual process that can be reversed.

Panchenko, Valentyn, and Eliza Wu. 2009. "Time-Varying Market Integration and Stock and Bond Return Concordance in Emerging Markets.” Journal of Banking \& Finance, vol. 33, no. 6 (June):1014-1021.

Using nonparametric tests and data from 1995 to 2005 for 18 emerging markets, the authors find that stock and bond returns decouple after market integration.

Patro, Dilip K. 2005. “Stock Market Liberalization and Emerging Market Country Fund Premiums.” Journal of Business, vol. 78, no. 1 (January):135-168.

The author uses a sample of 34 closed-end funds from 18 emerging countries for 1981 to 1999 . It is found that market liberalization increases asset prices.

Patro, Dilip K., and John K. Wald. 2005. "Firm Characteristics and the Impact of Emerging Market Liberalizations." Journal of Banking E' Finance, vol. 29, no. 7 (July):1671-1695.

Using data surrounding the liberalization for 18 countries, the authors examine the benefits of liberalization at the company level. There are considerable differences in the benefits depending on company characteristics.

Phylaktis, Kate, and Lichuan Xia. 2006. "Sources of Firms' Industry and Country Effects in Emerging Markets.” Journal of International Money and Finance, vol. 25, no. 3 (April):459-475.

The authors use data from 1990 to 2002 for 37 countries and find that a company's level of integration affects its stock response to global effects, country effects, and industry effects. The implication is that companies with less foreign sales and an ADR listing provide the most efficient diversification in emerging markets.

Puchkov, Anton V., Dan Stefek, and Mark Davis. 2005. "Sources of Return in Global Investing." Journal of Portfolio Management, vol. 31, no. 2 (Winter):12-21.

The data are for developed and emerging markets from 1992 to 2004. Country effects continue to dominate global effects in emerging markets.

Raju, Guntur Anjana, and Harip Rasulsab Khanapuri. 2009. "Regional Integration of Emerging Stock Markets in Asia: Implications for International Investors.” Journal of Investing, vol. 18, no. 3 (Fall):31-39.

Six markets in Asia (China, India, Indonesia, Malaysia, South Korea, and Thailand) are examined for integration. It is found that the markets are not entirely integrated.

Roosenboom, Peter, and Mathijs A. van Dijk. 2009. "The Market Reaction to Cross-Listings: Does the Destination Market Matter?” Journal of Banking E Finance, vol. 33, no. 10 (October):1898-1908.

Using data for 526 cross-listings for 44 countries' companies, the authors find that U.S. listings produce the largest gains, with the gains attributable to the improved disclosure and investor protection in the United States. 
Sarkissian, S., and M.J. Schill. 2009. “Are There Permanent Valuation Gains to Overseas Listings?” Review of Financial Studies, vol. 22, no. 1 (January):371-412.

Examining cross-listings in 25 countries, the authors find that cross-listing does not result in longterm valuation gains or lower costs of capital.

Schacht, Kurt, James Allen, and Matthew Orsagh. 2009. Shareowner Rights across the Markets: A Manual for Investors. Charlottesville, VA: CFA Institute.

This reference describes shareholder rights in 10 developed markets and 12 emerging markets. Each market's environment is thoroughly described in separate reports.

Schill, Michael J. 2008. "New Perspectives on Investing in Emerging Markets." Charlottesville, VA: Research Foundation of CFA Institute.

This literature review of emerging market research discusses the unique features of emerging market investing, including those of information inequities, illiquidity, poor investor protection, and increased market integration.

Silva, Ana Cristina, and Gonzalo A. Chavez. 2008. "Cross-Listing and Liquidity in Emerging Market Stocks." Journal of Banking E Finance, vol. 32, no. 3 (March):420-433.

A sample of data from 1992 to 2001 is used to demonstrate that the liquidity benefit of cross-listing depends on the size of the company and country of origin.

Solnik, Bruno, and Dennis McLeavey. 2009. Global Investments. 6th ed. Boston: Pearson Prentice Hall. This text is a comprehensive treatment of global investing issues and includes coverage of foreign exchange determination, asset pricing, equity investments, bond investments, risk management, and performance measurement.

Sullivan, Rodney N. 2008. "Taming Global Village Risk." Journal of Portfolio Management, vol. 34, no. 4 (Summer):58-67.

Investors underpriced risk partly because of a decline in economic volatility. Markets are complex adaptive systems, and their risk cannot be easily described. Cognitive biases lead to poor risk management, market misevaluations, and volatility. To better measure risk, managers should account for these biases, the interconnectedness of markets, advances in technology, and mathematical models.

Teo, Melvyn. 2009. "The Geography of Hedge Funds." Review of Financial Studies, vol. 22, no. 9 (September):3531-3561.

Emerging market hedge funds with a physical presence in a country outperform distant funds by 9.97 percent annually. Data are from 2000 to 2006 for Asian funds.

Thapa, Chandra, and Sunil S. Poshakwale. 2010. "International Equity Portfolio Allocations and Transaction Costs." Journal of Banking E Finance, vol. 34, no. 11 (November):2627-2638.

The sample of data from 2001 to 2006 is for 36 emerging market countries. Emerging markets with higher transaction costs attract fewer developed world investment funds.

Tokat, Yesim, and Nelson W. Wicas. 2004. "Investing in Emerging Stock Markets." Journal of Wealth Management, vol. 7, no. 2 (Fall):68-80.

The authors examine the risk and return of emerging markets over market cycles and over the longer term. 
Umutlu, Mehmet, Levent Akdeniz, and Aslihan Altay-Salih. 2010. "The Degree of Financial Liberalization and Aggregated Stock-Return Volatility in Emerging Markets.” Journal of Banking E Finance, vol. 34, no. 3 (March):509-521.

The relationship between emerging market liberalization and volatility is examined, with volatility decomposed into global, local, and idiosyncratic volatility. Using data from 1991 to 2005, the authors find that liberalization reduces volatility by reducing local and idiosyncratic components.

van der Hart, Jaap, Gerben de Zwart, and Dick van Dijk. 2005. "The Success of Stock Selection Strategies in Emerging Markets: Is It Risk or Behavioral Bias?” Emerging Markets Review, vol. 6, no. 3 (September):238-262.

Using data from 1988 to 2004, the authors find that the success of value, momentum, and analyst earnings revision strategies is likely because of behavioral explanations, not risk.

van der Hart, Jaap, Erica Slagter, and Dick van Dijk. 2003. "Stock Selection Strategies in Emerging Markets." Journal of Empirical Finance, vol. 10, no. 1-2 (February):105-132.

The authors use data from 1982 to 1999 for 32 emerging countries. Portfolios are formed both within countries and globally. Excess returns are found by ranking on value/growth, momentum, and analysts' earnings revisions. 